\title{
Kemampuan Mengasosiasikan Soal Cerita "Peluang" Siswa Tunanetra melalui Metode Penemuan Terbimbing
}

\author{
Evita Gadis Permatasari ${ }^{1}$, Endro Wayhuno ${ }^{2}$, Eka Promono Adi ${ }^{3}$ \\ ${ }^{1}$ SDLBN Bendo Blitar \\ ${ }^{23}$ Universitas Negeri Malang \\ e-mail: evitagadispermatasari@yahoo.com
}

\begin{abstract}
Abstrak: Tujuan penelitian ini mengetahui : (1) efektifitas metode penemuan terbimbing, (2) peningkatan kemampuan siswa dalam mendeskripsikan soal cerita ke dalam bahasa matematika, (4) perbedaan kemampuan mengasosiasikan soal cerita "Peluang" sebelum dan sesudah intervensi. Penelitian ini diterapkan pada siswa yang mengalami ketunanetraan ketika dewasa dengan intellegensi rata-rata. Penelitian ini menggunakan metode SSR dengan desain A-B-A-B. Kondisi (A-1) kemampuan awal siswa sebelum dilakukan intervensi dengan skor $18 \%$. Kondisi (B-1) pelaksanaan intervensi dengan skor $80,4 \%$. Kondisi (A-2) kemampuan siswa sesudah dilakukan intervensi dengan skor $66 \%$. Kondisi (B-2) analisa kesalahan mengerjakan pada kondisi A-2 dengan skor $87 \%$. Metode penemuan terbimbing efektitif untuk meningkatkan kemampuan mengasosiasikan soal cerita peluang.

Kata kunci: metode penemuan terbimbing, kemampuan mengasosiasi, matematika, tunanetra
\end{abstract}

\begin{abstract}
The purposes of this study were to determine: (1) the effect of guided discovery method in the form of working guide modul (2) upgrading the student ability to describe about story excercises into math language (3) the association ability of "Peluang" story excercise between before and after implementation of guided discovery method. This study was SSR using the A-B-A-B desain. The Baseline condition-1 (A-1) to determine the begining student ability before intervention with score of $18 \%$. The Intervention Condition-1 (B-1) implementation of guided discovery method with an average score of $80.4 \%$. the Baseline condition-2 (A-2) implementation to determine student ability after the (B-1) with a score of $66 \%$. The Condition Intervention-2 (B-2) after working error analysis in the A-2 conditions with score of $87 \%$. Guided discovery method is effective to improve the ability to associate a story about chance.
\end{abstract}

Keywords: guided discovery method, association ability, math, student with visual impairment

Matematika merupakan pelajaran wajib bagi siswa dari jenjang pendidikan dasar hingga jenjang pendidikan tinggi, baik dari sekolah reguler hingga sekolah khusus. Pembelajaran matematika di sekolah khusus atau sering disebut dengan Sekolah Luar Biasa (SLB) disesuaikan dengan tingkat kemampuan siswa, kebutuhan siswa, serta tingkat ketunaan siswa. Pembelajaran matematika pada siswa tunanetra yang memiliki intellegensi (IQ) dengan kategori ratarata atau di atas rata-rata, dapat dilakukan dengan melakukan modifikasi pembelajaran yang disesuaikan dengan kebutuhan siswa. Siswa yang mengalami tunanetra sejak lahir dengan siswa yang mengalami tunanetra ketika remaja, ada beberapa perbedaan dalam gaya belajarnya. Menurut $\operatorname{Karim}$ (2011: 6) "Siswa yang mengalami hambatan penglihatan/ ketika dia memasuki usia remaja cenderung mengandalkan pengalaman visualnya dalam memahami bentuk soal matematika".

Gaya belajar siswa cenderung mengandalkan kemampuan auditorinya, padahal pembelajaran matematika memerlukan pemahaman konsep seperti dalam (Hudoyo, 2005:4)“ Dalam matapelajaran matematika siswa seharusnya lebih banyak berlatih mengerjakan soal untuk mengetahui konsep-konsep dasar dalam sebuah persamaan. "Pengenalan simbolsimbol matematika dalam huruf braille sangat diperlukan untuk melatih kemampuan siswa" Tajudin (2004:5). Penggunaan metode penemuan terbimbing dirasa mampu meningkatkan kemampuan mengasosiasi pada siswa tunanetra dalam matapelajaran matematika bab Peluang.

Berdasarkan permasalahan yang dijumpai di lapangan tersebut, maka dapat dirumuskan mengenai bagaimana kemampuan siswa dalam mengasosiasikan soal cerita "peluang" sebelum dan sesudah diterapkannya metode penemuan terbimbing. Tujuan dalam penelitian ini secara umum digunakan untuk meningkatkan kemampuan dalam mengasosiasi atau menalar memalui pengenalan simbol beserta hakikat peluang, menuliskan persamaan peluang, membaca persamaan peluang, menerjemahkan bentuk soal cerita ke dalam bahasa matematika, dan kemampuan mengerjakan berdasarkan modul panduan mengerjakan yang dituliskan dalam bentuk braille.

\section{METODE}

Penelitian ini menggunakan pendekatan Single Subject Research (SSR) dengan menggunakan desain penelitian A-B-A-B. 
Tabel 1. Rekapitulasi Pengukuran Desain A-BA-B

\begin{tabular}{ccc}
\hline Sesi & Kodisi & Nilai (\%) \\
\hline Pelaksanaan kondisi & A-1 & $18 \%$
\end{tabular}

A-1 (sesi 5)

Skor rata-rata (S.R) pada kondisi $\quad 18 \%$ baseline-1 (A-1) dalam $\%$

Menuliskan simbol $\quad$ B-1 $75 \%$

"Peluang" dan

"Peluang" (sesi 1)

Menghafal dengan

"Pembaca persamaa

"Peluang" (sesi 2)

Menuliskan

yang didektekan ole

peneliti (sesi 3)

Menganalisis jenis-

jenis soal cerita

"peluang" (sesi 4)

Penerapan metode

pemenuan terbimbing

penggunakan modul

dalam bentuk braille

(sesi 5)

Skor rata-rata (S.R) pada kondisi $\quad 80,4 \%$ intervention-1 (B-1) dalam \%

$\begin{array}{lll}\text { Pelaksanaan kondisi } & \text { A-2 } & 66 \%\end{array}$

A-2

\begin{tabular}{lccc}
\hline Pelaksanaan & kondisi & B-2 & $87 \%$ \\
\hline
\end{tabular}

B-2

Pada desain subjek tunggal "penelitian variabe terikat atau perlakuan sasaran (target behavior) dilakukan secara berulang-ulang" dalam Sunanto (2006: 41). Variabel dalam penelitian ini terdiri atas variabel bebas dan terikat. Variabel bebas adalah metod penemuan terbimbing, sedangkan varibel terika adalah kemampuan mengasosiasikan atau kemampua menalar. pemilihan desain A-B-A-B digunaka untuk memberikan penguatan pada pelaksanaan intervensi-2 (B-2) untuk mengoptimalkan kemampua mengasosiasi siswa sesuai dengan target behavio Subjek dalam penelitian dengan menggunakan metod SSR ini adalah siswa yang mengalami tunanetra ketika remaja kurang lebih pada usia 17 tahun, denga ategori intellegensi (IQ) rata-rata atau diatas rata-rat.

Instrumen penelitian dengan menggunakan task analyisis yang disusun berdasarkan pembagia sesi dalam setiap kondisi. Task analysis digunakan sebagai pengukuran tingkat pencapaian siswa (a) disusun dala setiao kondisi. Kondisi A-l, terbagi menjadi 2 se yaitu kesiapan belajar dan latihan soal sebelum mendapat intervensi. Kondisi B-1 terbagi menjad 5 sesi yaitu, kemampuan menulis simbol, membac persamaan, menulis persamaan, identifikasi masalah, serta pelaksanaan prosedur mengerjakan dalan penerapan metode penmuan terbimbing. Kondisi A-2 merupakan latihan soal setelah mendapat interven B-1. Kondisi B-2 terbagi menjadi 2 sesi, merupakan penguatan pengetahuan siswa berupa analisa kesalahan mengerjakan A-2 dan pelaksanaan latihan sebagai

\section{HASIL DAN PEMBAHASAN}

Hasil

Pelaksanaan desain A-B-A-B digunakan untuk 政 Pelaksanaan desain A-B-A-B tchagi dalam setiap kondisi. Berikt adalah rekapitulas pengukuran pada desain A-B-A-B.

Bentuk peningkatan kemampuan siswa dapat diukur berdasakran semakin berkurangnya frekuensi kesalahankesalahan mengerjakan berdasarkan hasil perhitungan dalam task analysis. Berkurangnya frekuensi kesalahan ditandai perubahan skor yang pada setiap kondis sebelum intervensi (A-1) dengan kondisi (A-2) sesuda intervensi. Pada kondisi (A-1) siswa menyelesaikan soa dengan kemampuan berdasarkan pengalaman belajarny sendiri dengan skor 18\%, nampak bahwa kemampua siswa sangat kurang sehingga memerlukan pemahama terhadap konsep dasar dan makna dari hakekat peluang. pada kondisi (A-2) merupakan kemampuan siswa tela mendapat intervensi berupa hakekat, konsep dasa dan prosedur mengerjakan sehingga diperoleh has $66 \%$. Perubahan skor sebesar $48 \%$, terlihat dari car mengerjakan, dan semakin berkurangnya frekuensi kesalahan yang dilakukan siswa.

Pelaksanaan kondisi (B-2) diberikan untuk memberikan penguatan agar kemampuan siswa menja optimal, dan hasil belajar siswa menjacapi kriteria ketuntasan minimal yang sudah ditargetkan. Penguatan diberikan berupa analisa kesalahan-kesalahan mengerjakan yang masih terjadi pada kondisi (A-2), berdasarkan hasil analisa tersebut diharapkan tidak mengulang kelasahan yang sama dan mampu mengerjakan secar tepat. Berdasarkan pelaksanaan (B-2) kemampuan siswa dalam mengasosiasikan soal cerita meningkat sebanyak $21 \%$, sehingga skor siswa saat ini adalah $87 \%$, dalam kategori di atas rata-rata, dalam kondisi ini siswa tela mampu secara mandiri menyelesaikan berbagai bentuk soal yang berkaitan dengan bab Peluang, hanya saja teta memerlukan ketelitian dalam menghitung hasil akhirnya.
Tabel 2. Rangkuman Hasil Analisi dalam Kondisi

\begin{tabular}{lcccc}
\hline \multicolumn{1}{c}{ Kondisi } & A-1 & B-1 & A-2 & B-2 \\
\hline $\begin{array}{l}\text { 1. Panjang } \\
\text { kondisi }\end{array}$ & 6 & 5 & 1 & 2 \\
\hline $\begin{array}{l}\text { 2. Estimasi } \\
\text { kecenderu } \\
\text { ngan arah }\end{array}$ & stabil & naik & naik & naik \\
\hline $\begin{array}{l}\text { 3. Kecenderu } \\
\text { ngan } \\
\text { stabilitas }\end{array}$ & stabil & stabil & stabil & stabil \\
\hline $\begin{array}{l}\text { 4. Estimasi jejak } \\
\text { data }\end{array}$ & & & & \\
& & & & \\
& & & & \\
\hline $\begin{array}{l}\text { 5. Level } \\
\text { stabilitas } \\
\text { dan rentangan }\end{array}$ & 15 & 15 & 15 & 15 \\
\hline 6. Perubahan & & & & $100 \%$ \\
level & & & & \\
\hline
\end{tabular}

Tabel 3. Rangkuman Hasil Analisis antar Kondisi

Perbandingan $\quad$ B-1/ A-1 $\quad$ B-2/ A-2 Kondisi

\begin{tabular}{ccl}
\hline Jumlah Variabel & 1 & \multicolumn{1}{c}{1} \\
\hline $\begin{array}{c}\text { Perubahan } \\
\text { kecenderungan } \\
\text { arah }\end{array}$ & $\begin{array}{c}\text { dari } \\
\text { stabil ke } \\
\text { meningkat }\end{array}$ & $\begin{array}{l}\text { mengalami } \\
\text { peningkatan } \\
\text { A-2 dan } \\
\text { semakin } \\
\text { meningkat pada } \\
\text { B-2 }\end{array}$ \\
\hline $\begin{array}{c}\text { Peruabahan } \\
\text { kecenderungan } \\
\text { stabilitas }\end{array}$ & $\begin{array}{c}\text { stabil ke } \\
\text { stabil }\end{array}$ & stabil ke stabil \\
\hline Perubahan level & 48 & 21 \\
\hline Presentase ovelap & $0 \%$ & $0 \%$ \\
\hline
\end{tabular}

Guna mengetahui tingkat perbandiangn dalam kondisi, maka dilakukan analisis dalam kondisi untuk mengetahui peningkatan kemampuan mengasoas dalam setiap kondisi desain penelitian A-B-A-B.

Berdasarkan tabel hasil rangkuman tersebut dapat disimpulkan bahwa kecenderungan arah menunjukkan bentuk peningkatan yang dialami oleh siswa berdasarkan perlakukan pada setiap kondisi yang cenderung meningkat, dengan kecenderungan stabilitas yang ditunjukkan dalam setiap kondisi. Perubahan level menunjukkan bentuk perubahan yang teerjadi pada setiap kondisi yang dibandingkan. Tanda $(+)$ menunjukkan adanya peningkatan terhadap kemampuan mengasosiasikan soal cerita Peluang. Analisis antar kondisi untuk mengetahui perubahan kondisi antar kondisi digunakan sebagai perbandingan dalam setiap kondisi yang ada. Berikut adalah rangkuman hasil analisis antar kondisi.

Analisis antar kondisi, digunakan untuk mengetahui bentuk perbandingan peningkatan antar kondisi. Dalam analisis antar kondisi, kondisi yang digunakan sebagai perbandingan adalah kondisi B-1 terhadap kondisi A-1 (B-1/A-1) dan kondisi B-2 terhadap A-2 (B-2/A-2).

Berdasarkan perubahan kecenderungan arah dapat dilihat pada tabel (B-1/A-1) kondisi stabil mendatar menjadi stabil meningkat, perubahan level menujukkan adanya peningkatan berdasarkan hasil perbandingan yang ditunjukkan dengan semakin berkurangnya yang ditunjukkan dengan semakin berkurangnya
frekuensi kesalahan mengerjakan. Presentase overlap menunjukkan adalah pengaruh penerapan metode penemuan terbimbing dalam bentuk modul panduan mengerjakan yang ditulis dalam huruf braille.

Presentase overlap menunjukkan metode sebut memberikan pengaruh terhadap kemampuan mengasosiasikan atau kemampuan menalar terhadap matapelajaran matematika bab Peluang. Presentase overlap semkin mendekati $0 \%$, menjukkan semakin efektifnya metode yang digunakan dan grafik kecenderungan arah menujukkan kondisi yang stabil. Kestabilan dapat terlihat dari perubahan kecenderungan stabilitas yang menjukkan perbandingan antar kondisi kondisi (B-1/A-2) dari stabil ke stabil. Dapat ditarik kesimpulan bahwa peningkatan kemampuan siswa dipengaruhi oleh kondisi B-1 berupa penerapan metode penemuan terbimbing dan dilakukan penguatan pengetahuan pada kondisi B-2 berupa analisa kesalahn mengerjakan.

\section{Pembahasan}

Berdasarkan desain penelitian A-B-A-B bahwa metode penemuan terbimbing dalam bentuk modul panduan mengerjakan memberikan pengaruh terhadap penampuan mengasosiasikan soal cerita dewasa. "Ketunanetran ketika dewan ketika crusak an mara mata diakibatkan karen ecelakan, virus, atau penyakit yang terjadi pada usia 017 thun" (dal, Wahyuno, 2013). Pada pasi iswa yang meno kan yengami beberapa kendala, seperti “" mosi atu rentap end kemandekan dalam belajar" (dalam Gardner, 2013). emiliha metode pembelajern sangat diperlukan cuna menoptimalkan kemampun siswa matapelajaran matematika. Menurut Hamalik dalom 
Adi (2013) menyatakan bahwa metode penemuan terbimbing merupakan kemampuan belajar seca eksperimental dalam menemukan konsep (discover) learning).

Pembelajaran menjadi bermakna apabila, "siswa menemukan sendiri konsep atau pengetahuan" (dalam Russefensi, 2006:65). Metode penemuan terbimbing mengajarkan kepada "siswa untuk melakukan kegiatan secara aktif dan berfikir kritis terhadap suatu permasalahan yang dihadapi" (Rochmadianah dalam Karim, 2011). Proses berfiki secara aktif, kritis berdasarkan "penemuan konse (discovery learning) merupakan suatu bentuk proses berfikir dengan menalar" (dalam Markaban, 2006). Keefektifan metode penemuan terbimbing yan disusun dalam bentuk modul panduan mengerjakan dapat meingkatkan kemampuan mengasosiasika terlihat dari skor pencapaian dalam kondisi. Kondis A-1 sebelum intervensi $18 \%$, merupakan kondisi siswa yang belajar secara sendiri dengan kategori sanga kurang. Berdasarkan perolehan tersebut maka dap dilihat adanya kesalahan belajar pada siswa, dima "belajar merupakan suatu perubahan perilaku hasil dari suatu pengalaman" (Hitipeauw, 2008).

Kondisi B-2 merupakan pemberian interven berdasarkan tahapan dalam metode penemuan terbimbing yang ditulis dalam huruf braille. Peluan merupakan salah satu materi dalam matematika, dimana memerlukan beberapa tahapan dalam "proses penyelesaiannya seperti, berfikir secara analogi, definisi istilah, pengetahuan struktur, kaitan dengan lingkungan" (dalam Tanjudin, 2004:12). Pada kondisi ini lebih menekankan dalam "penyampaian mater diperlukan modifikasi yang terletak pada materi da penggunaan media ajar yang mendukung" (dalam Pradopo, 2005). Pelaksanaan kondisi B-2 ini bertujua untuk membekali siswa dalam hakekat dan konsep awa peluang, dengan skor rata-rata yang terbagi menjadi sesi sebesar 80,4\% .

Kondisi A-2, merupakan kemampuan siswa setelah mendapat intervensi dengan kemampuan siswa sebesar $66 \%$. Berdasarkan pelaksanaan kondisi A-2, kemampuan siswa dalam matapelajaran matematik mengalami beberapa peningkatan, seperti memelik sebuah kajian, dapat berfikir secara deduktif, dapa menuliskan sebuah simbol, dan memecahkan masala (Soedjadi, 2000). Kondisi pada A-2 kemampuan siswa berada dalam kategori mampu secara rata-rata, namu memerlukan beberapa penguatand alam mencapa target hasil belajar.

Kondisi B-2, merupakan pemberian penguatan terhadap kesalahan yang dilakukan pada kondisi A-2 dengan skor siswa sebesar $87 \%$. Pada kondisi ini terlih perbedaan makna belajar bermakna dengan belaja secara mengahfal berdasarkan hasil dari pelaksana

intervensi dan sebelum pelaksanaan intervensi.
"Belajar menghafal merupakan cara belajar yang merupakan belajar dengan mencoba menghubungkan fenomena baru ke dalam stuktur pengetahuan dalam setiap masalah" (dalam Heruman: 2007).

Berdasarkan hasil peneletian dengan desain A-B-A-B, yang bertujuan meningkatkan kemampua mengasosiasikan atau kemampuan menalar soa cerita bab Peluang pada siswa tunanetra denga menggunakan penerapan metode penemua terbimbing dapat dikatakan efektif. "Metode penemua terbimbing dapat meningkatkan kemampuan penalara (asosiasi), kemampuan untuk berfikir, menumbuhka keingintahuan, dan merancang siswa dapa menemukan suatu konsep" (Trihastuti 2009 dalan Arynda, 2012: 124). Kefektifan tersebut dapat dilih berdasarkan peningkatan hasil belajar siswa yang tela mencapai target, dengan nilai ditas KKM. Kemampua mengasosiasi merupakan suatu pola membangu proses berfikir yang aktif.

\section{KESIMPULAN DAN SARAN}

\section{Kesimpulan}

Kemampuan mengasosiasikan atau kemampuan menalar pada siswa yang mengalami ketunanetraan ketika dewasa, dapat dioptimalkan dengan pemilihan pmebelajaran dengan menerapkan ssitem menemuka sendiri konsep, langkah, dan teori dirasakan efektif terhadap masalah siswa dengan karateristik tersebu Metode penemuan terbimbing dirasa efektif karen dapat meningkatkan kemampuan mengasosiasi ata menalar pada matapelajaran matematika bab Peluan Peningkatan dapat terlihat dari berkurangnya frekuen kesalahan mengerjakan dan perolehan skor siswa yan mengalami peningkatan dari sebelum pelaksanaan intervensi dan sesudah pelaksanaan intervensi.

\section{Saran}

Bagi pihak guru matapelajaran perlu membuat mengajarkan kepada siswa cara membuat rangkuman sederhana atau catatan mengenai buku kumpulan rumus yang sesuai dengan materi yang disampaikan membuat buku panduan berupa contoh-contoh soa ang berkaitan dengan materi yang disampaikan. Serta saran bagi pihak peneliti yaitu penyusunan modu disesuaikan dengan materi dan kemampuan siswa, modifikasi penyampainan materi sangat diperlukan agar siswa lebih mudah memahmai dan mengajarkan

dia hadapi.

\section{DAFTAR RUJUKAN}

Arynda, et.al. (2012). Penerapan Metode Penemuan Terbimbing dengan Pendekatan Kontekstual dalam Meningkatkan Kemampuan Belajar Aritmatika Sosial. Jurnal Pendidikan Matematika,
Online 3(3): 122-132 (www:http//jurnal.unej. Online 3(3): 122-132 (www
ac.id) diakses 3 Februari 2016.

Karim, A. (2011). Penerapan Metode Penemuan Terbimbing dalam Pembelajaran Matematika untuk Meningkatkan Pemahaman Konsep dan Kemampuan Berfikir Kritis. Jurnal Ilmu Pendidikan, (Online), 1 (1): 21-32, (ht

Wahyuno, E. (2013). Orientasi dan Mobilitas. Malang: Universitas Negeri Malang.

Tajudin, H. (2004.) Analisis Perkembangan Kemampuan Belajar Matematika Luar Biasa/A. Jakarta: Universitas Syarif Hidayatullah.

Hudoyo, H. (2005). Pengembangan Kurikulum dan Pembelajaran Matematika. Malang: UM Press.

Heruman. (2007). Model Pembelajaran Matematika. Bandung: PT Remaja Rosdakarya.
Gardner, H. (2013). Multiple Intellegences. Jakarta: Daras Book.

Hitipeauw, I. (2008). Belajar dan Pembelajaran. Malang: UM.

Adi, I .P. (2013). Penerapan Metode Penemuan Terbimbing untuk Mengingkatkan Pemahaman Siswa pada Materi Gradien di Kelas 8 SMPN 9 Palu. Jurnal Pendidikan Matematika, (Online), 1 (1): 76-78, (http://fkip.inila.ac.id/journal/ pendidikan) diakses 3 Januari 2016.

Sunanto, J. (2010). Pengantar Penelitian dengan Subjek Tunggal. Bandung: UPI

Markaban. (2006). Model Pembelajaran Matematika dengan Model Penemuan Terbimbing. Yogyakarta: Departemen Pendidikan Nasional Pusat Pengembangan Penataran Guru Matematika.

Ruseffendi, E. T. (2006). Pengajaran Matematika Modern untuk Orangtua Murid Guru dan SPG. Bandung: TARSITO.

Soedjadi, R. 2000. Kiat Pendidikan Matematika di Indonesia (Konstasi Keadaan Masa Kini Menuju Pendidikan Tinggi Departemen Pendidikan 